\section{In Vitro Screening of 76 Strawberry Cultivars for Twospotted Spider Mite Resistance}

\author{
Rosa María Giménez Ferrer, Joseph C. Scheerens ${ }^{2}$, and W. Alan Erb ${ }^{3}$ \\ Department of Horticulture, Ohio State University, Ohio Agricultural Research \\ and Development Center, Wooster, $\mathrm{OH} 44691$
}

Additional index words. Fragaria xananassa, Fragaria moschata, Tetranychus urticae, leaf disk, bioassay

\begin{abstract}
Leaf disk bioassays based on oviposition and damage accrued during 72 hours were used to screen 76 strawberry (Fragaria spp.) cultivars for resistance to the twospotted spider mite (Tetranychus urticae Koch). Oviposition rates (eggs/female per day) and damage scores were both highly variable, allowing cultivars to be classified, according to a combination of these two variables, into six categories of susceptibility or resistance: highly susceptible- 'Canoga', 'Ozark Beauty', 'Scott', and 'Tangi'; resistant-'Aiko', 'Annapolis', 'Apollo', 'Bounty', 'Cardinal', 'Douglas', 'Dover', 'Fairfax', 'Fern', 'Floridabelle', 'Glooscap', 'Governor Simcoe', 'Hecker', 'Kent', 'Pajaro', 'Parker', 'Rainier', 'Redcoat', and 'Vesper'; and highly resistant-'Profumata di Tortona' (F. moschata Duch.). Bioassay based on oviposition rates and damage scores was considered to be an efficient method to eliminate susceptible accessions from a breeding program, but authentication of putative resistance may require further testing in vivo.
\end{abstract}

Tetranychus urticae, the twospotted spider mite (TSSM), is one of the most serious pest problems in cultivated strawberry (Fragaria xananassa Duch.) fields in warm and dry climates, such as that of California and Florida (Oatman and McMurtry, 1966). Estimates indicate that, on average, the Florida strawberry industry alone experiences annual crop losses attributable to TSSM of $10 \%$ to $20 \%$ (\$10 million to $\$ 20$ million/year), even with the use of conventional cultural practices and

Received for-publication 11 May 1992. Accepted for publication 11 Jan. 1993. Journal article no. 13992. Salaries and research support provided in part by state and federal funds appropriated to the Ohio Agricultural Research and Development Center and by private funds acquired through the Ohio State Univ. Research Foundation. We gratefully acknowledge partial funding from the North American Strawberry Growers Association. In addition, we thank Franklin R. Hall and Roger N. Williams for expert advice given throughout the study and Richard K. Lindquist for use of facilities. The cost of publishing this paper was defrayed in part by the payment of page charges. Under postal regulations, this paper therefore -must be hereby marked advertisement solely to indicate this fact.

'Graduate Research Associate. Current address: Gabino Barreda 28, Educadores Satélite, 33100, Mexico City, Mexico.

${ }^{2}$ Assistant Professor. To whom reprint requests should be addressed.

${ }^{3}$ Associate Professor. acaricides (C.K. Chandler, personal communication). Similar estimates for British Columbia were made by Raworth (1986).

Strawberry breeders have found significant differences in tolerance levels and in antibiotic or antixenotic response to TSSM infestation within diverse $F$. ×ananassa germplasm collections in Arkansas, California, Florida, Kentucky, Washington, and Poland (Barritt and Shanks, 1981; Chaplin et al., 1970; Kishaba et al., 1972; Schuster et al., 1980; $\mathrm{R}=$ resistant, $\mathrm{HR}=$ highly resistant.

${ }^{y}$ Oviposition (eggs/female per day).
Shanks and Barritt, 1975). Other species within the genus, particularly the beach strawberry ( $F$. chiloensis L.), have also proven to be potential sources of resistance to TSSM (Luczynski et al., 1990; Shanks and Barritt, 1984), as well as to some insects, such as the strawberry aphid, Chaetosiphon fragaefolii Cockerell (Shanks and Barritt, 1984). Resistance in strawberries is heritable (Barritt and Shanks, 198 1; Chaplin et al., 1970; Schuster et al., 1980), but resistance expression among genotypes may vary considerably according to sampling date, year, and location (Barritt and Shanks, 1981; Dabrowski et al., 1971; Hamilton-Kemp et al., 1988; Kishaba et al., 1972; Schuster et al., 1980 Shanks and Barritt, 1975, 1980, 1984).

Among strawberry genotypes, susceptibility or resistance to TSSM has been assessed routinely using relative mite population levels and host injury ratings on intact plants (Poe and Howard, 197 1; Rodriguez et al., 1970, 197 1; Shanks and Barritt, 1975). In contrast, Luczynski et al. (1990) appear to have been the first to consider oviposition on intact plants to evaluate $F$. chiloensis clones for resistance.

Leaf disk (LD) bioassays based on oviposition rates (eggs/female per day; EFD) have been used successfully to quantify resistance among host varieties in several species (AlAbbasi et al., 1987; MacDonald et al., 1971; Patterson et al., 1974; de Ponti, 1977). In vitro methods have the following two significant advantages: 1) they are relatively inexpensive and can be conducted more rapidly than field tests; thus, the number of genotypes evaluated in a given test period can be expanded and 2) they minimize environmental variation effects on test results. Admittedly, modifications in leaf tissue physiology may result from leaf

Table 1. Grouping strawberry cultivars via cluster analysis according to oviposition on leaf disks.

\begin{tabular}{|c|c|c|}
\hline \multicolumn{3}{|c|}{ Damage score } \\
\hline Cluster & ter mean $\pm \mathrm{sD}$ ) & Cultivars \\
\hline $1(\mathrm{HS})$ & $8.7^{y} \pm 0.00$ & Canoga \\
\hline $2(\mathbf{s})$ & $7.5 \pm 0.23$ & Ozark Beauty, Scott, Tangi \\
\hline $3(\mathrm{I}-\mathrm{S})$ & $5.9 \pm 0.36$ & $\begin{array}{l}\text { Albritton, Arking, Crimson King, Delite, Dunlap, Gilbert, Honeoye, } \\
\text { Jewel, Muir, Northwest, Oso Grande, Ourown, Pocahontas, Quinatt, } \\
\text { Selva, Shuksan, Sequel, Sunrise, Tennessee Beauty, Tristar, } \\
\text { Trumpeter, Sparkle, Totem }\end{array}$ \\
\hline $4(\mathrm{I}-\mathrm{R})$ & $4.9 \pm 0.31$ & $\begin{array}{l}\text { Benton, Blomidon, Catskill, Chandler, Dover, Earliglow, Ftetcher, Hood, } \\
\text { Jerseybelle, Lateglow, Marlate, Midway, Raritan, Redchief, Robinson, } \\
\text { Surecrop, Tribute }\end{array}$ \\
\hline $5(\mathrm{R})$ & $3.4 \pm 0.28$ & $\begin{array}{l}\text { Apollo, Atlas, Bounty, Cornwallis, Douglas, Fairfax, Florida 90, Glooscap, } \\
\text { Governor Simcoe, Guardian, Hecker, Kent, Lester, Micmac, Parker, } \\
\text { Rainier, Redcoat, Redglow, Solsmo, Sumas, Tloga, Veestar }\end{array}$ \\
\hline $6(\mathrm{HR})$ & $2.9 \pm 0.46$ & $\begin{array}{l}\text { Aiko, Allstar, Annapolis, Cardinal, Earlibelle, Fern, Floridabelle, Pajaro, } \\
\text { Profumata di Tortona, Solano, Vesper }\end{array}$ \\
\hline
\end{tabular}

${ }^{2} \mathrm{HS}=$ highly susceptible, $\mathrm{S}=$ susceptible, $\mathrm{I}-\mathrm{S}=$ intermediate to susceptible, $\mathrm{I}-\mathrm{R}=$ intermediate to resistant, 
detachment, which, in turn, may alter resistance mechanisms; however, comparing field and laboratory-based assay methods to assess resistance to TSSM among cucumber(Cucumis sativus L.) cultivars revealed that oviposition and preadult mortality on LD were not significantly different from those found on attached leaves as long as the duration of the in vitro bioassays did not exceed72h (de Ponti, 1977).

LD bioassays have not been used previously to classify relative resistance to TSSM among strawberry genotypes. The present study has explored advantages of using the bioassay technique, based on oviposition and damage scores, to identify potential resistance to TSSM within a wide range of strawberry cultivars serving as parents in a newly initiated breeding program.

Bioassay procedure. Fully expanded young leaves (third to fifth macroscopic leaf from the crown apex) were collected from 2-year-old, fruit-bearing plants of $75 F$. xananassa cultivars and one $F$. moschata cultivar maintained in field plots at Wooster, Ohio. Each cultivar was collected on one of 14 consecutive sampling dates in June 1990 (five to 10 cultivars per sampling date). Using a corkborer $(2 \mathrm{~cm}$ in diameter), LD were obtained from either side of the main vein from the terminal end of the central leaflet of each sampled trifoliate. Each LD was placed with the abaxial surface facing upon water-saturated nonsterile cotton circles contained in an open $35 \times 10$-mm petri dish.

Two-day-old, adult female (AF) TSSM were obtained from a colony reared on 'Henderson's Bush Baby' lima bean (Phaseolus lunatus L.) plants. The mites were transferred from the bean plants onto each LD with a camel hair brush (no. 00).

Two bioassays were performed simultaneously with each cultivar; for LD bioassay no. 1 (LDB 1 ), eight LD were infested with 15 $\mathrm{AF} / \mathrm{LD}$, whereas in LD bioassay no. 2 (LDB2), five $L D$ received five $A F / L D$. For each $L D B$, LD were completely randomized on stainless steel trays across a laboratory bench. After 72 $\mathrm{h}$, the EFD for each LD was recorded; damage to LD was estimated in LDB 1 using a scale of 0 to $10(0=$ no necrosis, $10=$ total necrosis $)$. Ambient temperature and humidity were recorded hourly by a $21 \mathrm{X}$ data logger equipped with a model 207 temperature and relative humidity probe (Campbell Scientific, Logan, Utah). Photoperiod and light intensity (provided by indirect sunlight and fluorescent room light) were not controlled,

The data were analyzed using SAS (1985) procedures and software. Analyses of variance (PROC ANOVA) were performed on all the data to identify the significance of the cultivar effect. Cultivar mean values were used in correlation analyses (PROC CORR) to test the consistency of the cultivar effect on oviposition at different population densities of females (e.g., EFD in LDB1 vs. EFD in LDB2), and to describe relationships between EFD and damage estimates. Cultivars were grouped by cluster analysis (PROC FASTCLUS) according to oviposition, damage, and both parameters simultaneous $\mathrm{y}$.

Bioassay conditions. Daily ambient tem- perature means (23 to $25 \mathrm{C}$ ) fell consistently within the optimum range for TSSM development (Nickel, 1960). Daily relative humidity means (39'\% to $58 \%$ ) were slightly higher than reported to be optimum by Nickel ( 1960), but they remained relatively constant throughout the study.

Oviposition. Mean oviposition was significantly higher $(P=0.0001)$ in LDB2 (five $\mathrm{AF} / \mathrm{LD}, \mathrm{X}=5.35 \mathrm{EFD}, \mathrm{SD}=2.30$ ) than in LDB 1 (15 AF/LD, $X=4.49 \mathrm{EFD}, \mathrm{SD}=1.77)$. Wrensch (1985) summarized reports of the adverse effects of high population density on ovipositional rates. Lower ova production per female and higher percentages of nonviable eggs have resulted from dense populations of spider mites, and the mortality of immature stages also has been associated with crowding. In other studies, population density markedly reduced reproductive indicators such as longevity, developmental rate, survivorship, and sex ratio. Accordingly, authors have concluded that the major elements influencing the rate of population increase are density-dependent.

Although mean oviposition levels were significantly different in LDB 1 and LDB2, the cultivar effect on EFD at the two infestation rates correlated strongly $(r=0.77, P=0.0001)$; ovipositional rates of' Sunrise' and 'Crimson King' were the only values inconsistent with this pattern. Therefore, oviposition values from both bioassays were combined for statistical analysis of cultivar effects.

Cultivars significantly influenced oviposition rates of TSSM females (ANOVA data not shown). 'Canoga' supported the highest levels of oviposition (X = 8.7 EFD) and was considered to be highly susceptible to TSSM infesta- tion on the basis of this criterion (Table 1). Susceptible cultivars Ozark Beauty, Scott, and Tangi were characterized by a cluster mean oviposition rate of $7.5 \mathrm{EFD}(\mathrm{SD}=0.23)$. In contrast, the lowest oviposition rate mean (X $=1.2 \mathrm{EFD}$ ) was observed on LD of 'Profumata di Tortona', one of 11 clones comprising the highly resistant cluster.

Although previous studies have used strawberry LDB to study mite behavior, survivorship, etc., they have employed evaluation criteria other than oviposition (e.g., egg viability and population growth) to assess differences among treatments and cultivars (Dabrowski and Rodriguez, 197 1; Dabrowski et al., 1971; Hamilton-Kemp et al., 1988, 1989; MacDonald et al., 1971; Rodriguez et al., 1970, 1971). Therefore, as ovipositional rates are seldom reported, there are few, if any, benchmarks with which to compare the rates observed in this study.

Damage score. Disks of 'Profumata di Tortona' and 'Rainier' were least damaged, suggesting an expression of resistance, whereas 'Blomidon', 'Chandler', 'Crimson King', 'Eadibelle', 'Jewel', 'Micmac', 'Ourown', 'Quinalt', 'Scott', 'Shuksan', 'Sparkle', 'Sunrise', 'Tangi', 'Tennessee Beauty', 'Tristar', and 'Trumpeter' displayed similarly high levels of LD damage (Table 2).

Some concordance was found between damage assessments on LD in the present study and those on intact plants made by other investigators (Table 3 ). In addition to the numerical similarity of the scores assigned to the same cultivars in other studies and to ours, their relative classification for resistance was also in agreement. 'Apollo' was in the intermediate to resistant group (I-R) in our study,

Table 2. Grouping strawberry cultivars via cluster analysis according to damage scores in leaf disk bioassay no. 1.

\begin{tabular}{|c|c|c|}
\hline \multicolumn{3}{|c|}{ Damage score } \\
\hline Cluster & er mean* SD) & Cultivars \\
\hline $1(\mathrm{HS})$ & $6.2 \pm 0.29$ & $\begin{array}{l}\text { Blomidon, Chandler, Crimson King, Earlibelle, Jewel, Micmac, Ourown, } \\
\text { Quinalt, Scott, Shuksan, Sparkle, Sunrise, Tangi, Tennessee Beauty, } \\
\text { Tristar, Trumpeter }\end{array}$ \\
\hline $2(\mathrm{~s})$ & $5.3 \pm 0.25$ & $\begin{array}{l}\text { Allstar, Atlas, Arking, Cornwallis, Earliglow, Fletcher, Gilbert, } \\
\text { Guardian, Lateglow, Midway, Oso Grande, Ozark Beauty, Solano, } \\
\text { Sequel, Sumas, Surecrop, Tioga, Tribute }\end{array}$ \\
\hline $3(\mathrm{I}-\mathrm{S})$ & $4.5 \pm 0.24$ & $\begin{array}{l}\text { Albritton, Canoga, Catskill, Delite, Fern, Hood, Lester, Florida 90, } \\
\text { Pajaro, Parker, Pocahontas, Redchief, Redglow, Robinson, Selva, } \\
\text { Totem, Veestar }\end{array}$ \\
\hline $4(\mathrm{I}-\mathrm{R})$ & $3.7 \pm 0.22$ & $\begin{array}{l}\text { Aiko, Annapolis, Apollo, Benton, Cardinal, Douglas, Dover, Fairfax, } \\
\text { Floridabelle, Glooscap, Governor Simcoe, Hecker, Jerseybelle, Kent, } \\
\text { Marlate, Muir, Northwest, Raritan, Redcoat, Vesper }\end{array}$ \\
\hline $5(\mathrm{R})$ & $3.0 \pm 0.13$ & Bounty, Durdap, Honeoye \\
\hline $6(\mathrm{HR})$ & $1.7 \pm 0.46$ & Profumata di Tortona, Rainier \\
\hline
\end{tabular}

${ }^{2} \mathrm{HS}=$ highly susceptible, $\mathrm{S}=$ susceptible, $\mathrm{I}-\mathrm{S}=$ intermediate to susceptible, $\mathrm{I}-\mathrm{R}=$ intermediate to resistant, $\mathrm{R}=$ resistant, and $\mathrm{HR}=$ highly resistant

${ }^{y}$ Rating scale of $0-10 ; 0=$ no necrosis, $10=$ total necrosis.

Table 3. Comparison of damage scores assigned to strawberry cultivars in several studies.'

\begin{tabular}{lcccc}
\hline Cultivar & $\begin{array}{c}\text { Present } \\
\text { study }\end{array}$ & $\begin{array}{c}\text { Poe and Howard } \\
(1971)\end{array}$ & $\begin{array}{c}\text { Chaplin et al. } \\
(1968)\end{array}$ & $\begin{array}{c}\text { Rodriguez et al. } \\
(1970)\end{array}$ \\
\hline & & Damage score & \\
Apollo & 3.3 & 1 & & \\
Florida 90 & 4.4 & $5-6$ & \\
Solano & 5.4 & 6 & 5.8 & \\
Surecrop & 5.3 & & & \\
Tioga & 5.0 & $4-7$ &
\end{tabular}

${ }^{2}$ Rating scale of $0-100=$ no necrosis, $10=$ total necrosis. 
and was considered resistant by Poe and Howard (1971). They also found 'Florida 90' and 'Tioga' to be susceptible, while we grouped them as intermediate to susceptible (I-S) and susceptible, respectively. However, there were cases in which resistance assessments in other trials were different than those we assigned, even when the injury scores were very similar. For instance, 'Surecrop' received similar injury scores in two greenhouse studies (Chaplin et al., 1968; Rodriguez et al., 1970), and these ratings were very close to the damage score that we assigned to 'Surecrop'. However, in those studies, 'Surecrop' fell into an intermediate classification, while we ranked it among the susceptible group. Conversely, damage scores for greenhouse-grown 'Northwest' were consistently and significantly lower than those for 'Rainier' and 'Totem', even when cultivar response varied according to date and location (Shanks and Barritt, 1975). In the present study, 'Northwest' received a lower damage score (3.5, I-R) than 'Totem' (4.2, I-S), but was considered to be more susceptible than 'Rainier' (2. 1, highly resistant). These discrepancies in classification may result in part from the range of cultivars tested in each study. Any cultivar's apparent susceptibility is always a relative measure; it depends on the relative susceptibility or resistance within the population to which the cultivar is being compared.

Overall performance. The correlation between EFD and damage scores among cultivars was modest ( $r=0.41, P=0.0002)$, and patterns of susceptibility and resistance among cultivars differed substantially when classification schemes were based independently on these two criteria (Tables 1 and 2). In 57 of 76 cases, most notably for 'Allstar', 'Atlas', 'Blomidon', 'Chandler', 'Earlibelle', 'Fern', 'Guardian', 'Micmac', 'Pajaro', 'Solano', 'Sumas', and 'Tioga', clustering based on damage score alone resulted in cultivars being classified as more susceptible than oviposition rates indicated. Accordingly, determining relative resistance accurately among cultivars may be more clearly established when mite response to host (oviposition) and host response to mite (damage score) are considered simultaneously as a measure of overall cultivar performance.

In a cluster analysis based on overall performance (Table 4), 'Profumata di Tortona' appeared to be highly resistant, while 'Aiko', 'Annapolis', 'Apollo', 'Bounty', 'Cardinal', 'Douglas', 'Dover', 'Fairfax', 'Fern', 'Floridabelle', 'Glooscap', 'Governor Simcoe', 'Hecker', 'Kent', 'Pajaro', 'Parker', 'Rainier', 'Redcoat', and 'Vesper' comprised the resistant class. 'Canoga', 'Ozark Beauty', 'Scott', and 'Tangi' appeared to be highly susceptible. Cultivars within cluster no. 2 (susceptible) had the highest cluster mean for damage score along with high oviposition rates. From this group, 'Selva' stands out as susceptible because of its importance in the industry.

In general, cultivar classifications assigned herein agreed with those cited in previous studies (Table 5). 'Apollo', 'Floridabelle',
'Solano', and 'Surecrop', found to express a degree of resistance to TSSM by LDB, were also reported to exhibit resistance characteristics using in vivo evaluations based on mite population levels, injury ratings, and yield reductions. Similar agreement in classification among methods was noted for the relatively susceptible 'Hood', 'Northwest', 'Raritan', 'Shuksan', 'Sparkle', and 'Totem'. In contrast, grouping 'Florida 90', 'Rainier', and 'Tioga' in relatively resistant clusters (Table 4) differed from previous data, suggesting that these cultivars are susceptible to TSSM infestations.

The above similarities or differences in cultivar rank notwithstanding, direct compari-

Table 4. Grouping strawberry cultivars via cluster analysis according to overall performance based on oviposition and damage score.

\begin{tabular}{|c|c|c|c|}
\hline \multirow[b]{2}{*}{ Cluster $^{2}$} & \multicolumn{2}{|c|}{ Cluster means $\pm \mathrm{SD}$} & \multirow[b]{2}{*}{ Cultivars } \\
\hline & $\overline{\text { Oviposition }}$ & Damage score $^{x}$ & \\
\hline 1 (HS) & $7.8 \pm 0.64$ & $5.4 \pm 0.59$ & Canoga, Ozark Beauty, Scott, Tangi \\
\hline $2(\mathrm{~s})$ & $5.9 \pm 0.46$ & $5.8 \pm 0.57$ & $\begin{array}{l}\text { Arking, Crimson King, Fletcher, Gilbert, Jewel, } \\
\text { Lateglow, Oso Grande, Ourown, Quinalt, Selva, } \\
\text { Shuksan, Sequel, Sparkle, Sunrise, Tennessee } \\
\text { Beauty, Tristar, Trumpeter }\end{array}$ \\
\hline $3(\mathrm{I}-\mathrm{s})$ & $5.3 \pm 0.45$ & $3.9 \pm 0.52$ & $\begin{array}{l}\text { Albritton, Benton, Delite, Dover, Dunlap, Honeoye, } \\
\text { Hood, Jerseybelle, Marlate, Muir, Northwest, } \\
\text { Pocahontas, Raritan, Redchief, Robinson, Totem }\end{array}$ \\
\hline $4(\mathrm{I}-\mathrm{R})$ & $4.1 * 0.57$ & $5.3 \pm 0.58$ & $\begin{array}{l}\text { Allstar, Atlas, Blomidon, Catskill, Chandler, } \\
\text { Cornwallis, Earlibelle, Earliglow, Florida 90, } \\
\text { Guardian, Lester, Micmac, Midway, Redglow, } \\
\text { Solano, Sumas, Surecrop, Tioga, Tribute, Veestar }\end{array}$ \\
\hline $5(\mathrm{R})$ & $3.5 * 0.53$ & $3.6 \pm 0.53$ & $\begin{array}{l}\text { Aiko, Annapolis, Apollo, Bounty, Cardinal, Douglas, } \\
\text { Fairfax, Fern, Floridabelle, Glooscap, Governor } \\
\text { Simcoe, Hecker, Kent, Pajaro, Parker, Rainier, } \\
\text { Redcoat, Vesper }\end{array}$ \\
\hline 6 (HR) & $1.6 \pm 0.00$ & $1.4 \pm 0.00$ & Profumata di Tortona \\
\hline
\end{tabular}

${ }^{2} \mathrm{HS}=$ highly susceptible, $\mathrm{S}=$ susceptible, $\mathrm{I}-\mathrm{S}=$ intermediate to susceptible, I-R = intermediate to resistant, $\mathrm{R}=$ resistant, $\mathrm{HR}=$ highly resistant.

'Oviposition (eggs/female per day).

${ }^{\times}$Rating scale of $0-10 ; 0=$ no necrosis, $10=$ total necrosis.

Table 5. Comparison of resistance rankings of common strawberry cultivars in various stales.

\begin{tabular}{|c|c|c|c|c|}
\hline \multirow[b]{2}{*}{ Cultivar } & \multirow{2}{*}{$\begin{array}{c}\text { Present } \\
\text { study }\end{array}$} & \multicolumn{3}{|c|}{ Previous studies } \\
\hline & & $\overline{\text { Ranking }}$ & Criteria & Reference $^{2}$ \\
\hline$\overline{A p 0110}$ & $\mathrm{R}$ & $\mathrm{R}$ & Iniury ratings & 7 \\
\hline Floridabelle & $\mathrm{R}$ & $\mathrm{R}$ & Yield reductions (\%) & 8 \\
\hline Florida 90 & I-R & $\mathrm{S}$ & Injury ratings & 7 \\
\hline Hood & $\mathrm{I}-\mathrm{S}$ & I & Injury ratings & 10 \\
\hline \multirow[t]{2}{*}{ Northwest } & I-S & I & Injury ratings & 10 \\
\hline & & $\mathrm{S}$ & Number of mites & 11 \\
\hline \multirow[t]{2}{*}{ Rainier } & $\mathrm{R}$ & I & Injury ratings & 10 \\
\hline & & $\mathrm{S}$ & Number of mites & 1 \\
\hline Raritan & I-S & I & Injury ratings & 10 \\
\hline \multirow[t]{2}{*}{ Shuksan } & $\mathrm{S}$ & I & Injury ratings & 10 \\
\hline & & $\mathrm{I}-\mathrm{S}$ & Number of mites & 11 \\
\hline \multirow[t]{2}{*}{ Solano } & $I-R$ & $I-R$ & Injury ratings & 7 \\
\hline & & I-S & Number of mites and eggs & 4 \\
\hline Sparkle & $\mathrm{S}$ & & $S$ number of mites & 5 \\
\hline \multirow[t]{3}{*}{ Surecrop } & $I-R$ & I & Injury ratings & 2 \\
\hline & & $\mathrm{I}-\mathrm{S}$ & Injury ratings & 8 \\
\hline & & $\mathrm{R}$ & Injury ratings & 13 \\
\hline \multirow[t]{2}{*}{ Tioga } & I-R & $\mathrm{I}-\mathrm{S}$ & Number of mites and eggs & 4 \\
\hline & & $\mathrm{S}$ & Yield reductions (\%) & 9 \\
\hline \multirow[t]{2}{*}{ Totem } & $\mathrm{I}-\mathrm{S}$ & $\mathrm{I}-\mathrm{S}$ & Injury ratings, number of mites & 10,11 \\
\hline & & $\mathrm{S}$ & Number of mites, injury ratings & 1,12 \\
\hline
\end{tabular}

HortScience, Vol. 28(8), August 1993 son of methodologies to determine the relative susceptibility or resistance of cultivars to TSSM infestation is difficult. Cultivar status assigned obtained in previous investigations because of differences in environment, experimental conditions and timing, levels of mite infestation, range of cultivars used. cen within a program (Barrit (19) Ferrer et al., 1993; Hamilton-Kemp 1988; Kishaba et al., 1972; Schuster et 1984). For Dabrowski et al. (1971), the relative ranking 
of cultivars according to TSSM population development was not consistent over 20 sampling intervals. Shanks and Barritt (1975), facing a similar situation when ranking accessions, emphasized the importance of testing two to three plantings over 3 to 4 years to ascertain a cultivar's susceptibility or resistance.

The advantage of using a combination of assay techniques to establish cultivar susceptibility or resistance was also evident within the Ohio program. For example, there was general agreement between the ranking of seven cultivars using the LDB technique and their relative TSSM susceptibility or resistance as determined in a subsequent in vivo study monitoring plant and mite performance over several mite generations (Giménez Ferrer et al., 1993). Nevertheless, because the in vitro technique criteria (EFD and damage) are but two among the complexity of variables that may engender TSSM resistance in the field, the in vitro classification of some cultivars (e.g., Rainier) and their behavior in vivo were disparate.

In conclusion, the LDB based on oviposition and damage score can be an effective method to identify cultivars exhibiting susceptibility to TSSM infestation in a temporally, spatially, economically, and labor-efficient manner. However, because the hostpest-environment relationship is extremely complex, phenotypically resistant cultivars identified by in vitro tests may not display resistant characteristics under field conditions. Therefore, the LDB as a technique could be used for preliminary screening of germplasm followed by complementary greenhouse or field studies using intact plants of bioassayselected phenotypes to authenticate putative resistance and to provide more detailed depiction of resistance patterns.

\section{Literature Cited}

Abbasi, S.H., J.L. Weigle, and E.R. Hart. 1987. Biological interactions between New Guinea Impatiens and the twospotted spider mite (Acari: Tetranychidae). J. Econ. Entomol. 80:4750.

Barritt, B.H. and C. H.- Shanks, Jr. 1981. Parent selection in breeding strawberries resistant to twospotted spider mites. HortScience 16:323324.

Chaplin, C. E., L.P. Stoltz, and J.G. Rodriguez. 1968 The inheritance of resistance to the two-spotted mite Tetranychus urticae Koch in strawberries, J. Amer. Soc. Hort. Sci. 92:376-380.

Chaplin, C. E., L.P. Stoltz, and J.G. Rodriguez. 1970 Breeding behavior of mite-resistant strawberries. J. Amer. Soc. Hort. Sci. 95:330-333.

Dabrowski, Z.T. and J.G. Rodriguez, 1971. Studies on resistance of strawberries to mites. 3. Preference and nonpreference responses of Tetranychus urticae and $T$. turkestani to essential oils of foliage. J. Econ. Entomol. 64:387-391.

Dabrowski, Z. T., J.G. Rodriguez, and C.E. Chaplin. 1971. Studies in the resistance of strawberries to mites. IV. Effect of season on preference or nonpreference of strawberries to Tetranychus urticae. J. Econ. Entomol. 64:806-809.

Giménez Ferrer, R. M., W.A. Erb, B.L. Bishop, and J.C. Scheerens. 1993. Host-pest relationships between the twospotted spider mite and strawberry cultivars with differing levels of resistance. J. Econ. Entomol. (In press.)

Hamilton-Kemp, T.R., R.A. Anderson, J.G Rodriguez, J.H. Loughrin, and C.G. Patterson. 1988. Strawberry foliage headspace vapor cornponents at periods of susceptibility and resistance to Tetranychus urticae Koch. J. Chem. Ecol. 14:789-796.

Hamilton-Kemp, T. R., J.G. Rodriguez, D.D. Archbold, R.A. Andersen, J.H. Loughrin, C.G. Patterson, and S.R. Lowry. 1989. Strawberry resistance to Tetranychus urticae Koch: Effects of flower, fruit, and foliage removal-Comparisons of air- vs. nitrogen-entrained volatile compounds. J. Chem. Ecol. 15: 1465-1473.

Kishaba, A. N., V. Voth, A.F. Howland, R.S. Bringhurst, and H.H. Toba. 1972. Twospotted spider mite resistance in California strawberries. J. Econ. Entomol. 65:117-119.

Leska, W., Z. Suski, and R. Leski. 1964. The infestation of various strawberry varieties by the strawberry mite (Steneotarsonemus pallidus Banks) and by the two-spotted spider mite (Tetranychus telarius L.). Proc. Inst. Sad., Skienuw 8:213-226.

Luczynski, A., M.B. Isman, D.A. Raworth, and C.K. Chan. 1990. Chemical and morphological factors of resistance against the twospotted spider mite in beach strawberry. J. Econ. Entomol. 83:564-569.

MacDonald, J. A., J. Root, R. Snetsinger, and R. Craig. 1971. Techniques for evaluating host resistance to the two-spotted spider mite, Tetranychus urticae. Melshemier Entomol. Ser. 44:1-4.
Nickel, J.L. 1960. Temperature and humidity relationships of Tetranychus desertorum Banks with special reference to distribution. Hilgardia 30:41100.

Oatman, E.R. and J.A. McMurtry. 1966. Biological control of the twospotted spider mite on strawberry in southern California. J. Econ. Entomol. 59:433-439.

Patterson, C.G., R. Thurston, and J.G. Rodrigues. 1974. Twospotted spider mite resistance in Nicotiana species. J. Econ. Entomol. 67:341-343.

Poe, S.L. and C.M. Howard. 1971. Relative susceptibility of selected strawberry clones and cultivars to spider mite injury. Proc. Fla. State Hort. Soc. 84:152-156.

de Ponti, O.M.B. 1977. Resistance in Cucumis sativus L. to Tetranychus urticae Koch. 2. Designing a reliable laboratory test for resistance based on aspects of the host-parasite relationship. Euphytica 26:641-454.

Raworth, D.A. 1986. Sampling statistics and a sampling scheme for the twospotted spider mite, Tetranychus urticae (Atari: Tetranychidae) on strawberries. Can. Entomol. 118:807-814.

Rodriguez, J. G., C.E. Chaplin, L.P. Stoltz, and A.M Lasheen. 1970. Studies on resistance of strawberries to mites. I. Effects of plant nitrogen. J. Econ. Entomol. 63:1855-1858.

Rodriguez, J. G., Z.T. Dabrowski, L.P. Stoltz, C.E. Chaplin, and W.O. Smith, Jr. 1971. Studies on resistance of strawberries to mites. 2. preference. and nonpreference responses of Tetranychus urticae and T. turkestani to water-soluble extracts of foliage. J. Econ. Entomol. 64:383-387.

SAS. 1985. SAS/STAT user's guide, version 5 ed. SAS Inst., Cary, N.C.

Schuster, J.F., J.F. Price, F.G. Martin, C.M. Howard, and E.E. Albregts. 1980. Tolerance of strawberry cultivars to two-spotted spider mite in Florida. J. Econ. Entomol. 73:52-54.

Shanks, C.H. and B.H. Barritt. 1975. Resistance of strawberries to the twospotted spider mite. J. Econ. Entomol. 68:7-10.

Shanks, C.H. and B.H. Barritt. 1980. Twospotted spider mite resistance of Washington strawberries. J. Econ. Entomol. 73:419-423.

Shanks, C.H. and B.H. Barritt. 1984. Resistance of Fragaria chiloensis clones to the twospotted spider mite. HortScience 19:640-641.

Wrensch, D.L. 1985. Reproductive parameters, p. 165-170. In: W. Helle and M.W. Sabelis (eds.). Spider mites, their biology, natural enemies and control. vol. la. Elsevier, Amsterdam, The Netherlands.

Wylie, W.D. and A. Haddox. 1974. Varietal resistance in strawberries to spider mites. Ark. Farm Res. 23:2. 